\title{
War Activities of College and Research Libraries
}

A summary of the war services of academic libraries based on a quick study by the librarian of Mills College for the A.C.R.L. Committee on War Activities. This work was made possible by the Emergency Fund of the A.L.A. under a grant from the Carnegie Corporation of New York.

$\mathrm{T}$

HE FOLLOWING brief review of the activities of academic and research libraries during the past year may well be termed a report of progress and should perhaps be read as a supplement to the report published in College and Research Libraries, December 194I, under the title "College and University Libraries and National Defense." The study, based on an elaborate questionnaire circulated several months before December 7, showed the academic libraries reflecting a rather tepid attitude toward national defense which characterized their respective institutions and the country as a whole before Pearl Harbor. To quote from the conclusion of the report:

A number of librarians expressed the opinion that the responsibility of the library for promoting study and understanding of the present crisis belonged more properly to the public library.... A majority believed that the college library could not make a significant contribution on its own.... The library was generally regarded as having met its responsibility if it made available materials on all aspects of these problems. ${ }^{1}$

${ }^{1}$ College and Research Libraries 3:18-30, December 1941 .
In the course of the year 1942 the picture has changed significantly as the nationwide awakening has affected academic institutions in varying degrees. Four hundred and eighty-eight colleges have been designated by the Army and $\mathrm{Navy}$ as possible centers for the specialized training programs, and many college halls and playing fields otherwise deserted are now filled with marching men. The large universities are centering their research efforts and facilities on scientific problems directed toward military purposes, often in buildings guarded night and day; the services of their experts in various fields of knowledge and the resources of their great libraries are devoted largely to governmental use. Education for peacetime living is continuing, to be sure, for certain groups and in certain places, but on the whole the colleges have gone to war, some regretfully, others with enthusiasm, all with a sense of dedication to fundamental purposes, with a desire to fulfill their obligations and with an attitude which is expressed by Dr. Harold W. Dodds, of Princeton, as the necessity of cooperating with the inevitable. In his annual report for I94I-42, the president of Princeton wrote:

The thing to remember is that the colleges and universities will find themselves by losing themselves in the war effort. Only by so doing can they fit themselves into the whole structure of this war which is a war of the people. If they remain aloof in this 
struggle, they cannot claim to be a part of the stream of civilization afterward. ${ }^{2}$

\section{The Role of the Library}

As might be expected, the role of the library in the activities of the institution varies in importance as it has always done. In a college where the library has been an active and positive force in the past it automatically becomes the center of information, and sometimes, as in extension or radio work, the library's staff is used not only in the planning but also in carrying out the new or enlarged programs, whether of specific instruction or general stimulation of interest. There are other institutions in which the library's function in the past has been strictly limited and often relatively unnoticed by those who made use of its facilities. Under the stimulus of the national emergency and the general desire in college communities as elsewhere for cooperative effort in the common cause or sometimes because of intense personal conviction as to the needs of the hour, the librarian has forgotten his traditional role-silence until spoken to-and now finds himself in a new position among the leaders in council, included ex officio in policy-forming bodies which plan for present war service and a continuous educational program. That today's problems offer the librarian this opportunity for increasing the effectiveness of the library and the realization of this increase on the part of administrative and governmental authority, few will deny, and it is the primary purpose of this report to make known to librarians throughout the field, in academic institutions differing widely in size and purpose, the varied opportunities for service. Many of the details reported seem trifling

\footnotetext{
${ }^{2}$ School and Society 56:428, Nov. 7, 1942.
}

in themselves-a short cut discovered, an instance of useful cooperation, a project that proved successful-but in the absence of general meetings it is the belief of the A.C.R.L. Committee on War Activities that a gathering together of suggestions should prove helpful. Some libraries will find their greatest usefulness in the field of research, others in the better understanding of vital war issues which they can encourage in the undergraduate student body. Still others, by their location, may be able to answer a need in the communities surrounding the campus. All alike share in the responsibility of educating the people, and each can best serve in its own way according to its talents.

\section{Conflicting Opinions}

Conversation with any group of college librarians brings to light the fact that there is still a fundamental difference of opinion as to the proper function of the library in today's world; and while there is no need to justify the undertaking of the committee, it might be well at the beginning to answer the most frequently heard objection to studies of this sort. The familiar argument of the college librarian, as he drops the questionnaire in the wastebasket, runs somewhat as follows:

Another one of these things? When I get time I'll write and tell that fellow that our job is one of educating the students of this institution and that we are trying to carry on as effectively as possible in spite of wartime difficulties. What we do in relation to information concerning the war, to spread the use of printed materials through all the means at our command, we have always done for any subject of current interest. We don't call it a "war activity" or publicize it as a stunt. Our regular reference service provides prompt answers to all 
queries for information without draping itself in flags and posing as a key center for civilian morale. Our task in this troubled time, as we see it, is to keep our heads, to avoid the contagion of hysterical activity, to recognize that our job is not to fight the war but to conserve the printed resources which will serve the cause of education hereafter and may help to build a lasting peace.

The composite opinion quoted above represents the honest view of many librarians, not necessarily dwellers in ivory towers, but men and women who believe that their most important function is to acquire, to conserve for the future, and to make available when sought, the records of the civilization which all alike seek to defend according to their powers.

In answer to this point of view the other librarian replies:

Of course our purpose is educational. Granting that we must carry our daily job and build for the future, that teachers and students to come must not be hampered by gaps in our essential collection, by arrears of uncataloged books, or by records which defeat their purpose through inaccuracy or incompleteness, isn't it equally true that our all-time task includes the present as well as the future? This war is the greatest event in our day and generation. Its progress and its outcome affect the life of every individual now and in the years to come. As citizens we are all sharing the burden. As librarians some of us occasionally have work to do which contributes directly to the military effort, but this is a restricted field limited chiefly to the reference and research service of highly specialized or unusually complete general collections. The service which is open to all of us today in large or small libraries is to help interpret this perplexing world to our public through the printed word.

To this the first speaker, who likes to think of himself as hard-boiled, replies:

So what? Haven't we always stood ready with the answers? What more can you do than have them ready when needed?

To which again the advocate of further activity maintains:

There are some libraries conceivably whose sole duty is to collect and preserve, but the library in a teaching institution which stands aloof today, with "custodial philosophy" or narrowed aims of purely academic education limited to college courses, will inevitably lose any vital relationship to the life and thought of this generation of students. The impact of the war on their lives is difficult to overestimate. Whether they view it as an adventurous world crusade in which they have a share or as a net in which they are caught, it overshadows all other events. If they live through this experience with no aid from books whether in the realm of information, guidance, or enlarged understanding, books will have little meaning for them and it is unlikely that they will turn to reading later. Thus we shall have missed our great opportunity.

\section{Basis of the Report}

It is because of faith in the immediate as well as the future value of the library's services that it seemed worth while to publish at this time a quick overview of what some libraries are accomplishing, often with inadequate resources in books and personnel, in the hope that such a record grouped by activities rather than by institutions (though necessarily incomplete) might prove useful to other libraries, seeking enlargement of their facilities, by presenting suggestions for possible action.

Unlike its predecessor, the survey published in I94I, the present report is not the result of exhaustive study or detailed investigation on a broad base, but rather a sampling taken from those libraries which answered a widely scattered inquiry 
and from a few others chosen for visits because of their geographical location, for unusual specific activities reported, or because they seemed to be typical of a number of other institutions. All sections of the country were represented in the replies received, and visits included institutions on the Pacific Coast, the Middle West, and the Atlantic Seaboard, covering all the types of libraries represented in the A.C.R.L. Information available at A.L.A. Headquarters in print and other materials on file has also been of great assistance. Thanks are due also to the many librarians who gave their time in letters and interviews to contribute the material for this report. Nevertheless, the limits of time available and the necessary restrictions on travel made many gaps inevitable, and the writer is aware that many interesting undertakings have been missed and that valuable services performed by various libraries are cited for only one. For all such omissions or implications we ask your charity-and hope that you will keep the committee informed henceforth as to your activities and plans.

\section{War and the Colleges}

The central importance of the library's function is ever-present in the minds of librarians, but it must be admitted of all academic libraries that they are merely parts of a larger whole, their services limited by the purposes of the institution, and their abilities by its fortunes. Previous wars have doubtless had their noticeable impact upon college halls but chiefly in leaving them empty for a time, their treasures guarded by those who seemed, in contrast with the young warrior, to be the aged or unfit. To preserve the enduring values of civilization through successive wars has been their task and their justifica- tion. But now the country calls upon its educational institutions to convert their programs and activities to perform services of immediate value to the war effort, often at the expense of their traditional purpose. The air is full of the conflict of opinion as to whether this is wisdom or folly, but an increasing number of addresses, articles, and academic reports indicates a growing consciousness of twofold purpose and responsibility on the part of the collegesto adopt all necessary measures of training required by the war emergency and somehow at the same time to maintain the standards of humane education which are theirs chiefly to guard. There is recognition that the basic function of education remains the same and that for certain individuals and population groups it must be carried on with as little dislocation as possible, but that the war adds other tasks thereto which are inescapable. These must be the war work of the academic world.

Briefly the picture presented by college campuses the country over is much the same. A war council, war activity board, or emergency committee has been set up by the administration. The loss in faculty men, whether directly to the armed forces or for special tasks required by the government, would seriously cripple the teaching program were it not for the corresponding loss in student bodies. Even so the shift of personnel and reassignment of subjects is a constant strain.

The greatest change is the shift in student population, the replacement of fouryear students by those whose professional academic program has been accelerated or by a still greater number who are inducted and returned to the campus for a short program of purely technical training. The Navy College Training Pro- 
gram has announced its purpose to disrupt as little as possible the academic work of the reservists now in college, but this is not true of the units training for the Army, whose bodies might be said to occupy campus space while their minds are elsewhere. There is common agreement on the tension and strain observable among college men and women, which is not to be wondered at. With many there is increased application to the work in hand, a desire to finish the job, but a probably greater number are marking time with a sense of futility. The picture was graphically presented by Fortune in the heading "The college student waits in the anteroom."

\section{Changes Reflected in the Library}

As might be expected, the visible signs of enlistment in the war effort vary widely among libraries. There are university buildings whose marble entrance halls still display the treasured incunabula, where there seems to be no appropriate place for poster, map, or reminder of the day's pressing need. But this is no proof that work of vital importance to the Army Map Service is not going on in an upper room. The reference department may be spending two thirds of its time in services which cannot be publicized because of their confidential nature in military plans. Another library, concentrating on its campus public and keenly aware of its task of keeping them informed, lines its entrance corridor with arresting displays, posters, maps, the daily news on bulletin boards, so that even he who runs is tempted to pause, look, and read, perhaps even to think. Some libraries succeed in achieving both types of activity.

"Education for War." Fortune 26:132-37, December 1942.

JUNE, 1943
Librarians' reports the country over indicate that changed conditions on the campus have made new demands upon them rather than diminished their work. The loss in student enrolment has naturally been shown in the drop in circulation statistics, but this is frequently counterbalanced by new demands for other services to be described in some detail below. In general it may be said that the type of service which any library can or should render, whether in time of war or peace, will depend on the character and purpose of the institution it serves, its location in relation to other libraries or agencies equipped to offer similar services, and its resources in printed material and personnel.

\section{The Library's Task}

While the great collections of university and research libraries are proving of inestimable value to the experts in many branches of government service, there is general recognition among thoughtful librarians that our primary task is education, that our part in winning the war is a minor one though our function in aiding understanding is essential. It follows then-almost a truism-that our first duty is to our faculty and students, to implement the curriculum, to supplement classroom teaching by providing the records which form the link between past and present, to aid the teacher, and to expand the ideas presented by him. The library also has a further duty in relation to the curriculum, to complement its incompleteness with regard to the limited number of courses which any one student takes, to make him aware of other fields of which he should have some knowledge.

To collect and make available the varied types of material necessary for this task, 
to select wisely from the stream of books, to keep collections in order without undue fussiness, to decide where completeness is important and when it may better be sacrificed to variety, is a task requiring not merely knowledge, wisdom, and foresight but the gift of prophecy and sometimes the blessing of luck. To accept this as our task is, in the eyes of some, to damn our philosophy as "merely custodial," but there can be no effective teaching or learning if someone does not supply the necessary means, and the records of civilization have become too numerous to be readily cared for by those who use them.

The present emergency has brought to vivid light the value of the library which has consistently in the past strengthened its collection by enriching areas in which it was already strong, by completing files, or by aiming at complete coverage in certain types of material. When information of a sort not often called for is needed, about the Solomon Islands, for example, mere willingness to serve will not suffice and the best publicity is of little use, but the library which has the official yearbooks or other publications of all the colonial possessions in the Pacific is, in this case, the one which passed the ammunition when needed.

While the current reference service of the great university libraries is necessarily confidential, it is permissible to state that during the past year the University of California Library has been used constantly by the Army and Navy authorities in search of detailed information concerning the war areas in the Pacific. Its map collection for this particular area and for the Far East in general proved the strongest in the country, though many other libraries have also proved invaluable for maps of other areas.
Numerous other examples of a library's proving useful because of systematic collecting could be cited. The University of Illinois had local Midwest newspapers which furnished the government one important index of group opinion not observable in the metropolitan press. The Naval School at Columbia, training men for colonial administration, was set up in New York City rather than elsewhere because the New York Public Library had for years preserved files not to be found elsewhere in this country in their entirety, the parliamentary laws, sessional papers, official gazettes, and departmental reports of all the leading countries, including their colonial possessions. The Detroit Public Library was unusually well equipped to provide reference service on conditions in India because this was one of the fields for export which had interested the motor industry, and the Army has used this information extensively in planning bases and in studying problems of transport and supply.

Many similar instances could be cited, not to imply that all libraries should collect everything. Obviously there is no value in complete files of unused material for the sake of symmetry, but if and when the material is needed, there will be no effective use of it unless it has been previously collected and preserved. $\mathrm{Li}$ brarians who see their chief service in terms of collecting need not apologize for their lack of modern advertising techniques as long as they make known their resources to qualified potential users, chiefly to other libraries which might call on them in case of need.

\section{Various Types of Activity}

Many scholars would agree with Dr. Marjorie Hope Nicolson, of Columbia 
University, that "the true end of a university is less the dissemination of learning through teaching than the accumulation of knowledge through research,"4 yet few librarians would deny that all libraries are concerned with the diffusion of information as well as the collection and preservation of its records, and even within a university the undergraduate students form a college public for whom the teaching function of the faculty is all-important. The varied activities of different libraries in relation to the war, nevertheless, fall naturally into patterns dependent largely upon the size, nature, and location of the library. One will be most useful for research. Another is concentrating its energies upon the undergraduate group. Still others have extended their functions to the surrounding community. Some few can do all three. One service is not more valuable to the war effort than another, since all are necessary to its final and permanent success. In a general report such as this, however, they must be recounted separately.

\section{Service to Research}

The provision of material for specialized research and of the trained personnel to do much of the searching is carried on chiefly in the libraries of the large universities, the technical colleges of engineering and agriculture, or the reference divisions of the large public research libraries in cities. The specific demands upon an individual library are often due to its strategic location in relation to the armed forces, as in California; to industry, as in Michigan and Chicago; or to government departments, as in Washington, D.C., and New York City. It is equally true, however, that the mousetrap theory still operates and the authorities have, in many instances, established bureaus of the government or branch offices of Army services in centers where they could most effectively use the resources of certain libraries. The Army Corps of Engineers has rented offices next door to the Engineering Societies' Library in New York. The Army Map Service has its principal branch offices in San Francisco and Chicago, though

\footnotetext{
4 Bulletin of the Association of American Colleges
} 27:5II-12, December 1942. it has searched the libraries of the country as well. Many government services and private industries employ special workers whose full time is spent in certain libraries. Others use the library or faculty personnel, and the choice of one institution for the work may be the result of expert knowledge available there rather than the material resources of the book collection. A type of skill not generally recognized by outside experts in the subject field is that of the experienced reference worker with a background knowledge of the subject who is often found in the large research libraries. The librarian of the Engineering Societies reports an instance of intelligent use of this skill by one government agency which employed the library on an hourly basis to do a piece of specific research. The reference assistant accomplished in five hours what, according to the librarian's estimate, would have taken the Washington official two weeks to do plus travel time and expense.

As suggested before, much of the reference work is confidential and cannot be publicized even in general terms. What 
is generally admitted is that it falls into two categories: the geographic and economic information necessary to the military services planning the invasion and occupation of an area, such as weather data for the Solomon Islands or the gauge of the railways in North Africa; or the technical research in scientific fields which differs from the usual research merely in the urgency of the need and the application to immediate ends. Such work is largely in the fields of chemistry, physics, radio, electronics, engineering, agriculture, and botany.

\section{Lending Research Materials}

Academic libraries throughout the country are, without hesitation, placing all their resources in these areas at the service of all those who are working to further the war effort. Former members of the faculty and alumni now at work for the government feel free to claim by mail the materials with which they are familiar on the campus. Library loan facilities are being employed more freely than ever before, and many hitherto restricted volumes are loaned without question when the need seems imperative. In other cases reproduced copies can be supplied instead, and both microfilm and photostat are widely used. The University of California microfilm service is extensively used by the government in a variety of ways, one of which is the sending of weather reports by air mail.

The supplying of maps for Army purposes has been referred to. This is one of the chief fields in which material for reproduction is in constant demand. Not only map collections from coast to coast have been combed for the necessary guides to invasion by land and sea, but old travel books, picture collections, and even post cards and lantern slides have been found useful in the location of strategic landmarks visible from the air. From these and from detailed portions of other maps, enlarged and specially reproduced, with unnecessary features excluded, the Army cartographers produce the necessary guides for bombing expeditions.

The picture collection of the New York Public Library was providentially enriched a few months before Pearl Harbor by the collection of the Japanese Tourist Bureau which has been put to good use by several government agencies. Similarly Columbia University Library had accepted for storage the library of the Japan Institute, Inc., the most extensive reference library on Japan outside that country, which adds immeasurably to the wartime importance of Columbia's East Asiatic collection.

\section{Foreign Languages}

Another example of useful service sometimes provided by the staffs of the large libraries is the translation of scientific articles, when needed, from periodicals in Slavic and other less-known languages. When little time is required for this it may be done as part of the reference service. If more lengthy work is necessary it is frequently done on outside time at an hourly rate by staff or faculty members who are competent. The language competence of hitherto unnoticed library workers is beginning to be recognized, and it is no longer surprising to find the demure cataloger of a university library compiling a Russian phrase book for U.S. merchant seamen or the scholarly professor of Arabic and Sanskrit engaged on a manual for Army officers who will need everyday Arabic phrases in Africa.

Another linguistic demand on the in- 
genuity, if not the foreign language ability, of the university librarian has been the need for teaching materials in the common vocabulary of little-known Eastern languages, which were represented in American libraries by ancient and purely literary materials if at all. The sudden call to teach Army and Navy officers not merely Japanese or Chinese but Mongolian and Manchurian sent the University of California library on the hunt for vocabularies in these languages. The material was found in widely scattered sources, frequently in private collections, was reproduced, and made ready in time. Pushtu and other East Indian languages have presented fewer difficulties because the British Army and Civil Service have long been schooled and examined in the various languages of the empire and simple teaching materials must be available. The whole field of language study has been enormously widened by the possibility of American troops and postwar workers of all sorts being stationed in any corner of the world. American linguistic isolationism is over, and the wideawake librarian will look over his dictionaries, grammars, and phrase books with a critical eye.

Siamese is being taught at the University of Michigan; modern Persian at Columbia; Hausa, Fanti, and the Arabic of North Africa at Pennsylvania; and Malayan at Yale. Many of the municipal colleges are offering extension courses in modern Greek, Hindustani, military French, and German. This is chiefly intensive drill in the spoken language largely without books and by the use of a native of the country whom the bilingual instructor uses as an example and a "prop," as it were, to give local color. The class is confronted with such problems as:

JUNE, 1943
"Here's your prisoner. Get what information you can out of him," or "Here's a villager. Find out what food's available."5

New emphasis in the regular college teaching of the better-known European languages, however, does send teachers of French, German, Italian, and Russian to the library asking for reading matter with a practical war-related vocabulary. French classes at Mount Holyoke are specifically related to the work of interpreters, censors, radio listeners, etc. At Mills the needs of overseas workers in Red Cross and related fields of social reconstruction work are considered. The opportunities for service abroad in teaching and library work are leading students to take a practical interest in speaking a foreign language.

\section{Improvement of Resources}

While many libraries report the satisfaction of discovering recognized areas of strength in their collections which justify past policies of acquisition, others have become conscious of weakness in special fields and, where possible, have taken immediate steps to improve. Many a liberal arts college has been forced by new demands to strengthen its resources in mathematics, physics, chemistry, and geography. Several report that funds hitherto required for European periodicals are now being spent on the purchase of scientific sets, either secondhand or in offset copies. The subscription to microfilm and offset issues of periodicals not otherwise obtainable is now possible and promises to become more widespread in practice, even after the war, when those which survive may prove to be extremely scarce and on paper which will

B Walker, C. R. "Language Teaching Goes to War." School and Society 57:369-73, Apr. 3, 1943. 
not last. Few colleges are able to accumulate periodical funds beyond the fiscal year, so many report other fields of expenditure for this surplus. Some use it to increase the salary. budget. More often it stretches the general book fund. The growing internationalism in the American outlook is reflected in many of these purchase plans. Material in English on Russian affairs is being steadily increased in many libraries. Latin American literature is a field of expansion almost everywhere in the country, indicating probably a previous weakness in Spanish and Portuguese except in certain localities. Interest in the Far East is indicated everywhere from California, where special collections in this field have long been maturing at the university, at Pomona, and at Mills College (for examples of three sizes) to Massachusetts, where the newly established Mei-ling Soong Foundation in honor of Wellesley's famous alumna bids fair to make that college a distinguished center of vital interest in the study of modern China and its needs. The clearly defined plan for this project and the philosophy of book selection as outlined by the librarian are models by which many a library could profit.

\section{Service to Faculty}

Members of the teaching faculty are a library's most important patrons because effective teaching related to specific books will send the students to the library more surely than any amount of visual publicity. Time and effort spent, therefore, in acquainting the faculty with library resources are never wasted. Many libraries content themselves with a passive attitude of cheerfully providing whatever aid is sought by the individual colleague but volunteering none, on the theory that the responsibility for knowing his field in the collection belongs to the teacher. Others, however, have discovered the value of direct action and not only send Professor $X$ the routine notice when books which he ordered arrive, but keep in mind his special interest, the subject of his own writing, or the new course he is planning and send him word of material noted or received, particularly in periodicals in fields other than his own, which might not come to his attention. The librarian at Bradley Polytechnic Institute skims through a number of journals regularly as they come to his desk, thereafter routing them for quick perusal to members of the faculty who might be interested in specific articles. The responsibility for doing this might easily be divided among staff members with comparable subject backgrounds. A similar service much appreciated in these days of rapid change is the practice of routing to the president, treasurer, or academic deans appropriate governmental or society publications affecting the institution and its educational opportunities. Incidentally, there is probably no more effective method of impressing the administration with the usefulness of library service than some of these intramural courtesies which are the daily rule in special libraries but are too often neglected in the academic world with the excuse that we lack the time.

Today there is an ever-increasing volume of important but ephemeral material pouring into the library from all sides. Much of it is of vital interest now in conveying graphically facts relative to the national or world situation and would be constantly useful in teaching if the instructor had it, in time. All too often it is filed away in the library in case of future need, which may never arise. 
Much of this would far better be distributed without record, used and lost if need be, unless more than one user is foreseen. As Keepers of the Book many of us are too prone to preserve all print as sacred, and it will be long before we live down the reputation we have earned, which is evidenced in the failure of every attempt to convince government officials that publications sent to libraries are actually-on occasion-read by some portion of the public. Washington stands fast by its belief that to distribute means to send to any other department on the campus, but not to the library, because, according to statements made verbally by two O.W.I. officials, "Librarians only keep things filed away."

\section{Library Publications}

Few college libraries can afford printed bulletins or have the ability to produce one which would equal that of the Baker Library at Dartmouth, but most of us could do more than we do in the way of carefully mimeographed matter of use or interest to the faculty. We could learn much from the public library's techniques in the matter of book lists. We might learn from our own art departments or our books on printing, something of layout and display. We could make a practice of duplicating and distributing more generously work which we frequently do for one department alone. We could arrange our monthly book lists by topics and by reader interest. This would be more effective than the complete accessions list by Dewey numbers which the library usually makes for its own records and frequently sends forth regardless of its forbidding effect. The Iowa State College list of books on "Understanding the War," soon to be published by the O.W.I., is an excellent example of a topical list compiled cooperatively by the library staff and the faculty.

We could cooperate more often than we do with departments of the college and with other libraries in the making of indexes, abstracts, and bibliographies (where these do not exist in print). And if we make them for local use, we could try to see that they are made available through some form of duplication, like the cooperative bibliographies issued jointly by the technology division of the Detroit Public Library and the Library of Congress. In this case the reference worker in technology prepares the bibliography and the Library of Congress issues it in some form of lithoprint. The two issued to date are Tanks and Other Track Laying Vehicles and Powdered Metals, and both have been serviceable to scientific technicians beyond the reach of the library's normal services. A similar project which might have been undertaken in the medical library of any university stands to the credit of Detroit's medical science department, viz., the $W$ ar and Medicine Index begun in 1940. Current medical journals are indexed for every reference relating to war, and recent articles of interest to special research projects carried on in Detroit are called to the attention of those in charge. The index is mimeographed and sent to medical libraries, Army medical officers, and industrial medical departments on request. Original journals are interloaned when necessary for research work, or films and photostats furnished. A new cooperative project, originating in the department of English at Columbia University and the National Council of Teachers of English, may soon bring forth a book, and the cooperation of librarians is being sought 
both in preparation and in publication. This is the "Guide to Comparative Literature for Inter-Cultural Relations," which is designed to cover the literature of all countries as it appears in English translation with special emphasis on the language groups in this country which form islands in our American cultural pattern.

\section{Service to Students}

\section{Students in Uniform}

From coast to coast with few exceptions librarians report little if any demand upon library service as yet by the Army and Navy training units, whose men are rapidly taking the place of the former undergraduate student body. Individuals among them who are habitual users of libraries naturally find their way to the desk when they have time, but these are few. Michigan reports one lonely private, holder of a Ph.D. in Greek, who was made happy by stack privileges, and everywhere such individual patrons are welcomed. The men in uniform are quite generally offered all the usual privileges of the library upon proper identification. In many of the smaller colleges the staff has gone further in making known its services and extending its welcome in writing, in notices, in announcements, or in personal contacts through the officers. This practice will undoubtedly bring some result.

The units differ widely in their official use of the library for study purposes. On some campuses reading rooms in the library building are rented as part of the facilities for training and the men march to and from them as to classes, study being supervised by their own instructors. But this can scarcely be called library use since their eyes do not wander from assigned textbooks. This is more generally true of the Army than of the naval units, for the Army training seems to be purely technical and military while the Navy program is designed to produce officers and includes subjects generally accepted as academic. Yet contradicting this report comes word from the Georgia School of Technology that in a unit of five hundred Army students, whose officers said that they would not need the library, approximately one hundred are there every day, studying, reading magazines, or listening to records in the music room. Wherever the naval, aviation, and preflight meteorological schools are stationed, the librarians report use of the general reading rooms, an interest in current magazines and in popular books, but many of the training programs are built upon a rigid scheme of hours which allows little or no free time for reading. The only course reported as requiring its students to use the library is aircraft radio at Illinois. Here the librarian was invited to instruct the class in methods of use.

\section{Music Hath Charms}

The University of Colorado reports one special use of its record library which might well prove popular elsewhere if offered. The Naval Intelligence group, enrolled for the intensive study of the Japanese language, has been assigned an entire floor of the library, which is kept open until midnight for their use. After 
eight hours of concentrated study of Oriental characters the men are too tired to read, but they will gladly listen to music, and the library's extensive record collection placed at their disposal is of real service. The director of libraries reports that "some of the men have confessed that these music programs are about the only thing that enables them to keep on an even keel emotionally." They are also provided with a room which is open to them throughout the twenty-four hours for listening to Japanese language records.

Colorado is also setting a fine example of carrying its library service wherever needed to help the men in uniform. Not content with aiding those who wish to follow a program of study, to whom all the facilities of the main library are open, they have set up in the quarters occupied by the Naval Radio Training School a library of detective stories and light fiction for the boys who want to read that kind of material in the little leisure they have.

These are only two suggestions of the way in which a campus library can help in the emergency. Many others will develop, and it seems certain that with the inauguration of the new training programs in the summer, which will return to the colleges a selected group of men for officer training with courses often of longer duration than a few weeks or months, there will be ample opportunity for the librarian who is awake and moreover believes in the value of the service he can offer.

\section{Classroom Service}

A lively and effective method of introducing library service to a new group of students has been practiced at Bradley Polytechnic Institute in Illinois. Here, in addition to the regular student body (normally 950, now 650), some I 500 persons are enrolled in the federally sponsored E.S.M.W.T. courses. According to the librarian most of these are mature people, aged 25-50, many holding responsible administrative positions in industry or business located near-by. In the years which have elapsed since their formal education ceased they have often come to rely on experience rather than books. Now they are seeking a new technical education to fit themselves for greater service in the emergency. Most of them are not familiar with the location or resources of the college library and come to the campus for this one class only, which generally meets for two hours at a time.

In this situation many a librarian would have considered his duty accomplished by a mimeographed notice or verbal announcement by the instructor, but the energy of a young and ably cooperative library staff under the leadership of an enthusiastic librarian is evidenced in the plan of "initial classroom service" started in the fall of 194I. A list of books and magazines pertinent to the subject is prepared for each class and distributed by the instructor. A selection of books is then taken to the classroom by a staff member at a time agreed upon with the instructor and a brief explanation of the library's resources and facilities given. The books are then examined by the students and may be checked out at once without delay. They are then returned to the library by the individual. No further classroom service is given, but the stimulus of this first contact has proved sufficient to insure continued independent use. Many classes have regular reports henceforth from their members on new material coming into the library. The fact that E.S.M.W.T. funds, controlled by the in- 
structors and used for equipment, have gladly been made available for new book purchases is understandable in the light of this service.

The potentialities of such classroom service are of course great. The idea is not new. It has been used to some extent in high schools and in small colleges. The larger institutions are inclined to protest immediately that all such schemes are impracticable in dealing with numbers. The middle-sized colleges generally say, "We haven't staff enough." It might be pertinent to point out that the Bradley library staff consists of three professionals plus student assistants. Some colleges with seven to nine hundred students have staffs of ten to fifteen trained people and probably do more complete cataloging. It is a matter of choice.

\section{The Forgotten Student}

But in all this war activity of research and of service to the forces and to new students from industry, what becomes of the regular undergraduate student in the library, if any such still exist? He does exist of course, though in many cases, particularly in the universities, he may seem forgotten. The women's colleges have as yet suffered no noticeable drop in enrolment. In the coeducational institutions there are still freshman and sophomore men too young to enlist or in deferred classifications. There are undergraduates preparing for medicine, engineering, and other professions who need their full academic training, however accelerated, and need library service geared to the new tempo of life and perhaps more essential than in the days of comparative leisure and undergraduate loafing.

What are the libraries doing for this student or what new demands does he make upon them? In general there is little positive demand. There is much, however, that the library could do to stimulate his thinking, to aid him in a time of confusion. Activities reported by the majority of libraries include war information centers, guidance concerning war services, assistance by providing much more current ephemeral material for student use and by providing additional material for new courses or new emphasis in old subjects, new and renewed efforts to aid in the interpretation of current events and to provide reading material which will help students to understand this perplexing world. Some of these topics must be dealt with in detail, but in general it may fairly be said that the regular undergraduate student has gone his way during the past year with college administrators and librarians, for the most part, devoting little thought to any special needs that he might have. To the president he is one of a diminishing group at the moment unimportant. He has, in many cases, necessarily been turned out of his dormitory. His study halls are needed for the men in uniform. In some of the large universities this means that the house libraries are closed, the college study is used for military purposes, and its undergraduate collection consequently combined with a general reserve room with closed stacks so that there is no place on the campus to invite a student's reading. Those librarians who sincerely believe that war and education are poles apart, that our sole function is educational and our chief duty to keep alive the values of humane civilization in a world gone mad, might seriously ask themselves whether in "doing just what we have always done for our students," as many of them report, they are doing enough for those students. Per- 
haps the students need, not something different, but more of the same.

\section{War Information and the Student}

The term "War Information Center" as used in library reports is confusing. Visits to a variety of institutions have shown that it may mean anything from a collection of war material (used by a speakers' bureau but kept in closed stacks) or a collection of O.W.I. pamphlets (in boxes behind the periodical desk) to a widely publicized office prominently situated in the main hall and functioning as a center of information along the lines made familiar in the public libraries. Where these exist they are designed rather to serve the surrounding community and will be treated as extramural activities. War information for the undergraduate student has meant chiefly data concerning the various services and his relation to the question of enlistment. All libraries have made this material accessible, and in many of the smaller institutions the librarian has been designated as the campus officer to coordinate all information concerning the services, the college, and the war.

Of greater effect on the library, however, is the war material required for new courses or new directions in standard subjects. Aeronautics has come to the fore and opens a wide field for development both technical and popular. Geography has been given a fresh impetus and units of courses are now concentrated on the Mediterranean, the Pacific Ocean, the Far East, North Africa, Latin America, etc. Libraries are called upon to supply not only books with the new global emphasis but quantities of pamphlet and periodical matter. Several theological seminaries report the addition to their curriculum of courses in global geography and interre- lated history. Cartography offers a new field for combining a training in science and art. War information films of various sorts are available and have been found useful in classes, forum discussions, etc. Public libraries have employed this technique more than the colleges. Librarians wishing information on the subject should consult the A.L.A. or the O.W.I. Bureau of Motion Pictures.

\section{The New Maps and Posters}

Almost all libraries have accepted the challenge to make people conscious of the global outlook by posting numbers of maps, not only maps of the war areas in the day's news but large-sized world maps in the new azimuthal-equidistant polar projection on the theory that if our eyes rest upon them constantly, the familiar Mercator projection of our school days will fade somewhat and our minds become accustomed to thinking in terms of the air distances which bring San Francisco so close to Chungking, and Chicago but a step from Moscow. For this purpose bulletin boards and the maps supplied by Life, Time, and the news services will help, but far more effective are the large colored maps which may be obtained at reasonable cost for decorative use. The professional journals are full of information as to sources of map material. Whether the building includes a special map room or not, the library is the logical center for a map collection. When maps are scattered in various departments for classroom use, a card catalog with record of location is kept in the library.

The war posters of the United Nations are available from many sources and furnish useful material for classes in design as well as decoration for the library and other campus buildings. The O.W.I. will 
supply the American ones in quantity and welcomes suggestions from librarians as to sizes and types desired. The British Office of Information has several series of most effective posters and enlarged photographs to lend. Librarians should consult the list of sources of posters published by A.L.A. and may obtain information as to future sources from the A.C.R.L. Committee on War Activities which will keep the lists up to date. ${ }^{6}$

\section{New Emphasis in Old Courses}

The emphasis in studying Spanish literature has shifted decidedly to the Western Hemisphere, and there is a general demand for books by Latin American authors as well as newspapers and periodicals from the lands to the south. The growing interest in Portuguese requires library materials from Brazil.

The effort of instructors to relate the curriculum to the problems of today and tomorrow is reflected in such new courses as "The German Mind," offered in one Western college, and "Racial and University Groups," on a Southern campus, and in the widespread announcement of courses in "Postwar Planning," "International Organization," "The Theory of the State," "Inter-American Politics," etc. Courses in European history are being reorganized with greater emphasis on Russia and the Scandinavian states. To all these curricular changes the libraries are responsive, searching for new materials and increasing departmental fund allotments where necessary.

\section{Aids to Study}

While there is no verifiable data on changes in the reading and study habits "Source List of War-Related
terials." Publicity
Ma- of students and all reports are necessarily subjective, the observations of librarians fall into only two groups, somewhat contradictory but probably indicating the reactions of two general types of students. On one side we hear that students are more serious, have reduced outside activities, work more intently, are keen on finishing the job. From many of the smaller colleges comes this report. The conflicting statement is that they are understandably restless, whether dreading or anticipating service before long, are hopeless about future opportunity, and feel oppressed with a sense of the futility of study at this time and therefore do only as much as is required to pass.

With the latter group the library has little to do as they are likely to avoid it until the night before an examination. With the earnest worker, however, the library staff has always been quick to cooperate, as evidenced now by an increase in special privileges to undergraduates (particularly those engaged in independent study programs), such as undated longterm loans, the use of carrells, and other aids formerly reserved for graduate students.

\section{Ephemeral Material and Documents}

One of the effects of the war noted in libraries of all sizes and types is the greatly increased demand for and use of pamphlet and documentary material. In the larger libraries which have always received (and frequently filed away or kept for cataloging) quantities of such paper, the change is chiefly one of trying to make such forms of print quickly available. Some colleges are keeping much of it displayed on racks and tables while current, filing the rest roughly by subject in pamphlet boxes easily 
accessible, making no record except for numbered serials. At the University of Michigan it is sorted in the order department and all new material segregated there for a week where it is looked over by reference and departmental librarians for decision as to what shall be cataloged, what duplicated, and where the remainder will be most useful. Much of it the reference department chooses to use freely and lose if necessary. Other colleges file by subject in boxes, using a colored reference card for each subject heading in the main catalog. All such material is heavily used as the basis of classwork, student themes, and panel discussions as well as for public addresses and radio programs by members of the faculty.

The importance of use despite the risk of loss is now generally recognized and in time this change of heart in the library world will doubtless become known to distributors. At present all librarians are bewailing the increased difficulty of obtaining publications from government offices at the very time when the government is setting up other offices designed to carry information to the people through libraries as well as other channels. The library often fails to receive publications discovered elsewhere on the campus. O.W.I., O.C.D., and the Office of Education themselves are dilatory, and in too many cases separate requests are necessary for each departmental pamphlet.

A procedure has already been set up by the Library Program Division of the O.W.I., and may soon be in effect, to issue regularly a "Library War Guide." By means of this librarians would be made aware, a month or so in advance, of subjects on which the government would concentrate information during a given period, with indications also given of what lists, reading materials, posters, etc., could be supplied to further this effort.

Another project is the plan for earlier and more complete listing and for the purchase of inexpensive documents promptly and with little effort by the use of special stamps or post cards obtainable at any post office. Regional offices for sale and distribution have also been proposed. The A.L.A. has made detailed recommendations to the government for the improvement of methods of sale and library distribution of official publications, and there seems to be at least the hope of better days to come. ${ }^{7}$

\section{Student Understanding}

There is an unfortunate fallacy in the faith of many of us that a reading list necessarily indicates a number of books read. Advertising is doubtless necessary in this day of conflicting claims on our attention, but it is not in itself an accomplishment but merely a hopeful means to that end.

Nevertheless, the college library in one aspect of its work-that of extracurricular student reading-might do well to evaluate its policies of purchase and circulation in the light of public library experience. For in this one field we share with the public libraries the voluntary nature of the reader's attitude. In general we are accustomed to the mill of the curriculum which grinds us a steady stream of patrons year after year, and often we apply to the circulating portion of our collection the methods and practices of a reference library. If the reading of any book not required for course work is regarded as solely for recreation this scantiness in

7 "Government Publishing in Wartime." College and Research Libraries 4:100-06, March 1943. 
the provision of one of the joys of life by university libraries is not perhaps of primary importance. Librarians differ in opinion as to the responsibility of an educational institution to do this. Some directors of university libraries admit regretfully that with the pressure of large student bodies they simply cannot undertake the task. But in today's crisis few will deny that an important, perhaps an essential, part of the education of this generation is information and guidance toward understanding the present crucial problem. Many of them are about to fight a war and will enter upon their citizenship, if at all, in a world which will need more than ever before a well-informed public opinion. They need to think and talk about these problems; they need the stimulus which comes from reading many opinions and points of view as well as factual information and experience of men in this and other countries.

Are they reading the current books, pamphlets, and magazines which will provide this stimulus, and if not, what agency will best further this aspect of their education? Few of them have time to frequent a public library as well as that of the college which is their chief source of supply for books. As to whether or not they do read, the reports, like those on morale, are bound to be subjective and conflicting, influenced by too many extraneous factors to be reliable. Yet they are suggestive. From a technical college in Louisiana comes a comment on the apathy and lack of interest on the part of students and faculty. In a large Midwestern university the readers' adviser reports that the students need relaxation and ask for "something not about the war." Yet Columbia's rental collection offers concrete evidence of a steady demand for the popular nonfiction of the day which is almost exclusively war-minded. In Swarthmore, as well as in all the women's colleges, there is-as might be expecteda definite, serious concentration on the problems of peace, international organization, and postwar reconstruction. In general, it is probably safe to say that from the evidence of observation (not statistics of circulation) there is more reading of this type being done in the smaller institutions and in those which have made a special effort to make these books tempting and obtainable with little effort.

\section{Books in Quantity}

In some of the libraries which have definitely accepted their responsibility to defend democracy by helping to clarify the issues of the conflict, the following methods have been used. First, a generous supply of readable books is purchased promptly, displayed prominently, and circulated freely. The practice common in university libraries of buying only one copy of such books for general circulation cannot be counted generous, nor even the habit of purchasing another copy when ten reserves are lined up waiting. This is an emergency. We must do something to influence thinking when it is needed without caring whether or not these books will have permanent value on our shelves. Many of them will wear out or disappear. Let the others be disposed of, if necessary, when obsolete.

In support of this policy the Baker Library at Dartmouth has for some time been purchasing multiple copies-ten or more on occasion- of books which in the opinion of the librarian were "imperatives," though not necessarily those chosen as such by outside agencies. These "books of the hour," chosen in advance because 
they seemed to offer a serious contribution to the issues of war and peace, are prominently displayed and have been steadily used by the college public. Last Train from Berlin has had the most readers, but The Coming Battle of Germany, The New Belief in the Common Man, Sabotage, They Were Expendable, and $A$ Time for Greatness have all been in demand and have justified their purchase. The librarian infers that larger quantities would be welcomed and adds, to calm the fears of anyone with traditional ideas concerning the use of endowed book funds, that the "book of the hour" plan is financed by the sale of surplus class duplicates. $^{8}$

The Iowa State College went even further and with funds especially secured for the purpose set itself to a campaign of spurring engineers and agricultural students to read and discuss some books likely to prove germinal. Fifty copies of such titles as Mission to Moscow, Last Train from Berlin, and Berlin Diary were purchased in the past year and widely scattered, without accessioning, in such centers as dormitories, fraternity houses, student union club rooms, and all the open-shelf reading rooms to be found on the campus. Informal dormitory discussions and interfraternity debates are held on the issues of the day, organized by a student speakers' bureau, on the basis of the books read. Some of this seed may fall on stony ground, but surely with such a sowing some will bear fruit.

Wellesley reports that half its regular funds for the purchase of general books are now spent on reading of this type, for which there is a steady demand. Any book about the war which is considered

\footnotetext{
8 Baker Library, Dartmouth College. Library Bulletin 4:9-10, December 1942.
}

worthy is purchased and kept in a changing collection in the central hall. Other copies purchased from a special fund are distributed through the house libraries. Mount Holyoke library received an anonymous gift of five hundred dollars for this purpose. This suggests the probability that almost any library could find an interested individual or organization to sponsor such a program. Columbia's rental library has been mentioned, and though the barrier of three cents a day may qualify the term "generous," this is a method which could be started in every library and is, in many, carried on at the loan desk with small collections. The one at Columbia is luxurious in its appointments: a large, light room with the air of a more than usually comfortable browsing room, all the latest books in shining cellophane jackets, all the popular book reviewing periodicals, and a philosophy of service which includes a free mailing list of the weekly mimeographed bulletin, "Books You Want to Read." The director reports that the collection pays its own expenses, receipts covering the cost of staff and service as well as book purchase. Candor compels us to admit that faculty and wifely consumption of mysteries may have a bearing on this prosperity, but there is general agreement that rental collections do pay!

\section{Library Bait}

Having obtained the books-in quantity we hope, but at least a few duplicated titles while they are hot-the usual methods of display can be used plus others. All libraries post book jackets on bulletin boards in the building. Try putting a few somewhere else on the campus. Try writing notes and annotations with a little more snap for the college paper. The 
editor would prefer to use short notes for fillers rather than the usual book review column which the students may skip. Send your first copy of a book to some member of the faculty whom you think it may ignite. Ask him to speak of it in class if he enjoys it, but if you have picked your reader well, be sure you have enough copies on hand, for this is the unfailing way to catch a stream of students.

One librarian has found informal reading groups in her home a good way to start demand for a book. A member of the faculty is invited to read aloud from and discuss his latest book enthusiasm, something he is bubbling to share; or, more often, the book is chosen by the librarian and "planted" with the instructor, also chosen for his personal ability to communicate enthusiasm or because the book is one which will interest him. A certain amount of food for nibbling, even in rationed days, can be provided. Student groups vary in size from ten to thirty-five a week, but these evenings by a fireside have their own value for those who come and their influence echoes in dormitory talk thereafter. Some of the books read this semester have been The Guilt of the German Army, A Time for Greatness, Listen Hans, And Keep Your Powder Dry, and Destination Chungking. Another Western college has found "Books and Coffee" at the union a popular meeting.

\section{Book Exhibits}

Nearly all libraries have an exhibit case with several hundred books displayed. In the large universities this often stands in the main hall and is invariably full, with a depressing effect of the same books being always there. This is probably not true, but the effect is the same and in general there is too little choice about the collec- tions. The boys at the loan desk just keep the case full!

A more effective method is to group books by reader interest. $A$ few at a time may be placed on a single shelf, with an arresting sign, "What Is Happening Now." Or a single volume may be placed in a bookrest labeled "Have you Read." If you use a bookcase, place a chair near it. Mills library finds a cushioned window seat on the stair landing the best spot to tempt a reader. Swarthmore has made its browsing room a comfortable place with an air of use, where a man would feel inclined to put his feet up. Instead of a permanent collection you find there small groups of readable books constantly changing. The Tower Room at Dartmouth is also famous for this atmosphere, and in many other colleges today there is a blessed tendency to move from the mausoleum which enshrined "a gentleman's library" toward scattered spots for relaxed reading, whether in stacks, patio, or other corners of the library.

One of the most important aspects is the recognition that books should be taken from the exhibit and circulated immediately, no matter how such gaps spoil the picture. The test of success is the speed with which the books disappear, and an alert staff can usually keep something on hand to refuel. Such mechanical devices as the "Imperatives" book shelf within a bulletin board are well known and might be widely used for other books. In libraries where exhibit techniques are studied and skilfully practiced the writer was convinced that the combination of bulletin board and book is the most successful and that the books themselves, waiting to be read, should not be separated from posters, lists, signs, or jackets.

One of the other most successful meth- 
ods of stimulating student interest practiced by librarians conscious of the pressing need today is staff participation in student groups meeting for discussion. Library cooperation with student forum chairmen is taken for granted; reading lists, shelf displays, and posters to build up the subject of the current forum topic will be the rule in any self-respecting library. But now, by way of greater effort, one member of the library staff at Ames, Iowa, contributes a fifteen-minute review of the factual news of the week, which precedes the discussion. Another participates in the regular faculty panel, which covers European and world affairs, being responsible for developments affecting Russia. Following the panel there is a question period and general discussion among the students. It is significant that on this campus the discussion is always preceded by the statement of fact and opinion from informed sources, among which the library is rightly assumed to be a basic element.

The use of a student library committee for cooperative planning of discussions, exhibits, methods of campus publicity, and promotion of student reading in general has proved successful in spreading interest throughout the residence halls in college libraries and is probably worth the time required for a regular monthly luncheon and occasional meetings with the librarian. Conversation with university librarians has brought out the fact that because of the nature of their work and the pressure of administrative cares few of them have any contact with students or are able to give any opinion as to what they are reading or thinking. Even in large institutions, however, it might be possible to delegate to an associate the task of forming some regular channel for this human contact, for which no amount of statistical data reported can be a wholly satisfactory substitute.

\section{Foreign Students}

With few exceptions the college libraries seem to have made little effort to discover or make use of the talents of the foreign students on the campus, though they are in many cases among our most constant patrons and their number in any one college is not likely to be so great that personal contacts could not be established. The usual international club more often expresses itself in a variety of food and folk dancing than in the literature of the several nations represented. An active librarian can do much to provoke discussion of what people read in different countries, what they think of our books, what seems funny to them, etc. In one college a special member of the staff is assigned to attend weekly meetings of the international club as a friendly adviser.

One library uses the language skills of its foreign students whenever possible to give them a feeling of contributing something. Another invites their comments on its collection in their native literature, asks their opinion of the value of the translated novels in the collection, or the value of other current authors from their country not represented in the collection. Often they can establish valuable exchange relations with their own colleges. Students from South America particularly are coming in ever-increasing numbers to our colleges on exchange, fellowships, and federal grants. Some of the Catholic institutions are bringing them at private expense for the sake of values in cultural interchange. These students are at first shy and diffident, hampered by their lack of facility in conversation, but they have 
much to contribute in our colleges; and the library, through its possession of books in their own language, is often the first place in which they feel at home, and if warmly welcomed they become genuine ambassadors of goodwill in both countries.

\section{The College and the Community}

\section{Beyond the $W$ alls}

The problem of adult community education has not hitherto been one traditionally associated with the colleges where town and gown have been conventionally separate, but universities have, through their extension divisions and some less formal channels, exerted a wider influence in the United States, particularly where they constitute the apex of a state's educational and agricultural system.

In this sense a college campus has always been a center of information but the project of key centers of information and training, as first inaugurated last year by the Federal Security Agency in connection with its program of civilian morale service, set up some I 50 of these bureaus in many colleges strategically located for reaching a surrounding community not otherwise supplied with a war information center in a public library. Though these have functioned with various degrees of success, it is safe to assume that in many cases links have been formed between college and community which will last beyond the emergency. This is particularly true in the smaller universities and the rural colleges where public library service is less likely to be available than in the cities. Where the college faculty is the community reservoir for information and speakers, the purpose of the government in establishing this program is primarily to promote the translation of printed materials into speech.
Examples of the organization and workings of the war information centers are too numerous to quote, and the different patterns employed have conformed to local needs. Some institutions have followed the University of Missouri's plan of moving several hundred selected volumes from their stacks to supply background for the current material in the center itself. Generally, however, this has been chiefly a service bureau with posters, pamphlets, and card files indicating the regular channels of information throughout the library. North Carolina and Minnesota are typical examples of state universities offering state-wide information services and distribution of materials in packets through the cooperative agency of the library and the extension division, which exercise a form of dual control over the war information center situated in the library. Michigan carries on much the same service to clubs, schools, and individuals through its regular library extension service, though the war information center on its campus is directed by the department of political science and housed in the league. Iowa State College Library is another which seems to permeate every phase of state activity, working through farm bureaus, county agents, home demonstrators, and the regular extension services of the college which are organized down to the final unit of "neighborhood leaders" in the rural townships. Colorado is an example of a state 
in which the colleges of agriculture and education and the university have sensibly divided their fields of responsibility for information in certain subjects and work cooperatively to serve according to their respective abilities.

In Utah the university reports extensive use of the library from an outside public, but this demand is largely for specific technical books, not for services such as those offered by the key centers. This indicates to the librarian that people get their information through the channels to which they are accustomed, the newspaper, the radio, the weekly magazines, etc.

Vassar College, which may be taken as typical of the smaller private college, is extending its war information service to the community outside, including six counties, largely by means of its war information library, war research council, and bimonthly "War Information News Letter," in which the war research council of the faculty evaluates the material currently received in the information library and prepares bibliographies of suggested reading. The library of war information is an open-shelf collection set up in the main hall, without supervision or record of use, serving chiefly as a center for the display of current materials on the war.

\section{Community Service in the Future}

Community forums on the college campus, in which members of the faculty, students, neighbors, and often visiting speakers meet for the discussion of problems common to all citizens, are not new but have been the practice for many years. The need for such cooperation is merely intensified by the emergency and has been met in all parts of the country by the enlargement of such programs into insti- tutes on "Women and War," "The Background of the War," "The Citizen and the War." In many of the women's colleges the machinery for integrated effort is already established through the student community service undertaken in field work connected with courses in sociology, nursery school training, occupational therapy, etc. But the purpose of this work in the past has been the preprofessional training of the student, as a part of the academic program, not primarily a cooperative enterprise for community good or adult education. It seems probable that further development in the near future and in the postwar years will be in the direction of using the facilities of all academic institutions far more widely for state-aided programs of adult education. A project now being considered in the Office of Education, with the advice of the various national associations representing the liberal arts colleges and others not used in the Army and Navy training programs, will seek means for conserving and making available for wider community use the values inherent in the colleges already established, many of which may otherwise stand empty. This program will affect the libraries in many ways, and librarians should stand ready to take part in it from the earliest planning stages in their own institutions. There will be new demands for service, probably for guidance in individual reading not motivated by a curriculum, with a new type of adult public and with possible enlargement of facilities to meet new conditions.

\section{Interlibrary Loan}

Meanwhile the extended services of most libraries are being offered less to direct community borrowers than through interlibrary loan wherever this is possible. 
All libraries report the relaxation of rules in this regard to meet emergency needs. Universities will lend materials hitherto restricted to reference use. The type of material required is generally in the field of science in periodicals or valuable sets of proceedings. Research libraries in the large cities, heretofore prevented by their governing law from permitting any book to go outside the walls except under judicial subpoena, are now mailing promptly whatever is essential to authenticated borrowers engaged in official work whether this can be done ordinarily through a library or not. In most institutions the volume of interlibrary loan traffic has increased rapidly although the University of California reports that its statistics in this department show a falling off, compensated by the large number of loans made directly to individual officers of government or industry whose requests come by mail, telephone, or messenger, within a radius of sixty miles of the campus. In these cases speed is always considered important and the library waives its peacetime procedure of requiring another library as responsible intermediary.

Nevertheless, it might be well to note that these departures from accepted interlibrary loan practices in answer to the need of the moment do not, in the opinion of the librarians concerned, constitute a reflection upon the justice or necessity of the code. Wails are heard in various libraries from New York to San Francisco that when a book goes to an office in Washington you might as well kiss it good-by; that government officials in haste themselves are notoriously irresponsible in the matter of returning; that insistent correspondence is often required; that the confusion resulting from the absence of important reference materials in a given research library, where everything is supposedly in place, results eventually in more lost time than the loan was designed to save. Owing to the large amount of material on loan from the Library of Congress, in response to the needs of research offices, a colonel in the Signal Corps will travel to New York in the confident hope of finding what he needs in the New York Public Library's supposedly immovable collection, only to find that the precious volume has gone to $W$ ashington to the office of a major general in the Service of Supply. The result is frustration and a confirmation of the librarian's conviction that they also serve who keep their material at hand to fill the greatest number of needs; yet one who refuses any loan is accused of obstructing the war effort. Librarians are mild people but sometimes they need to be tough.

\section{The Library and the Radio}

The popularity of radio book reviewing programs has been capitalized to some extent by public libraries, though success in this field is not conspicuous. Universities throughout the country have had their regular radio outlets, though $\mathrm{Chi}$ cago is perhaps the only one with a nationwide fan public. Many colleges likewise sponsor local radio programs regularly or at intervals and college librarians as individuals are occasionally invited as speakers, but it has not been the general practice of academic libraries to concern themselves with this medium of reaching a potential reading public.

Once more, however, the emergency creates the pressure and, in the effort to use every available means at their command for bringing forcibly to the public mind the need for thoughtful reading and discussion of books which help to clarify 
the perplexities which confront us, the library has taken to the air in many quarters. From Salt Lake City the librarian of the University of Utah writes of helping to organize a regular radio program to be known as "The University and the War," hoping thus to reach a wider audience than the university students, with war information based on a broader background of historical knowledge than are some of the channels of information to which it is accustomed. The Rush Rhees Library at the University of Rochester has undertaken the task of assembling and preparing the material for a weekly half-hour broadcast over a local station, in the form of a round table discussion. Pamphlets, periodical articles, and books on the specific topic were digested in the library and given to the speakers at least a week in advance of the discussion.

Iowa State College is again an example of what is perhaps being done by other libraries as well, unknown to the A.C.R.L. The regular radio extension program of weekly book chats continues, though its customary subjects, popular biographies, novels, books of travel, etc., are likely now to be those of war interest. In addition there are special discussions of informative books and other publications related to the war in which the need for an intellectual rather than an emotional approach is encouraged. The library sponsors a radio book club which enables listeners to obtain the books discussed by mail from the college library, the nominal fee being paid in coupons previously purchased as a subscription to the club.

The familiar charge of isolationism justly hurled in the past at many sections of the country, particularly the Middle
West, can no longer be applied to the states of Iowa, North Dakota, and Montana, whose leaders, at least, seem to a traveler to be thoroughly awake to the need of education which will produce understanding of the inescapable connection between international and local problems. The world is now closely knit together by innumerable ties but unhappily struggling in those bonds, each nation for its own freedom. In the realization that no one can be wholly free to stand alone, a group of educators in Iowa, including several librarians, has formed a Committee for Durable Peace, the aim of which will be a state-wide educational program on the problems of peace, embracing organizations of all types which can aid in stimulating thought, reading, and discussion on the practical question of what we as individuals, families, and members of special groups are willing to pay as a price for peace and what in return we shall gain from a peaceful world. It is expected that this committee will lead to the formation of a state council on education for a permanent peace, which is the form of organization adopted in the other states mentioned.

\section{Main Street Discusses the Peace}

There has been and will continue to be much discussion everywhere of postwar problems but too often it turns on what the British Empire should give up, what Japan should do, how Germany should be governed. The new and valuable element in this scheme and one which librarians elsewhere may be able to develop locally is the emphasis on the concrete and specific ways in which the people of Main Street are going to be affected by the postwar organization here and abroad. In other words we know what war costs. 
What will peace cost us in terms of daily living and what price are we willing to pay for the values of peace and freedom for which we now fight? The people of Iowa are setting out to consider this vital problem systematically and with energy, seeking the aid of qualified persons to help them clarify the issues involved. Some of the questions suggested for discussion are: Must the United States police the world? Should all nations have access to raw materials? What is the future of the British Empire? Can we trust Russia? Can Japan become a democracy? Can we compete with Argentina and Canada? What was wrong with the League of Nations?

Endless other questions suggest themselves, and no one assumes that Iowa will find all the solutions, but at least there's going to be a lot of interested thinking and talking amidst the tall corn this year, the people's talk, which is the lifeblood of democracy. To this blood bank the local library is a constant donor. It can be the focal point and source of the thoughtful reading which must precede intelligent discussion. A somewhat similar undertaking which is under way in the academic world is known as the Universities Committee on Postwar International Problems, of which Professor Ralph Barton Perry, of Harvard, is chairman. The nature of its work may be indicated by a report from Wellesley College library (though more than one hundred colleges and universities are cooperating). In a letter dated April 9, I943, Blanche Pritchard McCrum writes:

Wellesley has its own central committee on the subject and a number of subcommittees devoting their time to various aspects of the question. On each of these subcommittees there is a representative from the library staff who does the bibliographical work that is necessary. The librarian is chairman of the Subcommittee on Relief and Rehabilitation. The work of these committees looks to preparing a memorandum on the given topic, to working on solutions of problems sent out by Dr. Perry's committee, and to holding open meetings for faculty and students to spread abroad on the local campus accurate information. The library is the bibliographical center of the projects of all subcommittees and has done a great deal of buying and soliciting of material in support of the project.

\section{War Hits the Library's Budget}

Asked what effect the war has had on the internal affairs of the library thus far, the majority of librarians reply, "Very little, really, aside from the inconveniences which are universal and not peculiar to our profession." There have been budget cuts in some libraries, chiefly those in smaller endowed institutions where state provision for a biennium does not give even temporary security, but several of them have received special gifts or additions to endowment. The universities and the state colleges report the usual allotments, some of them even reporting increases in salary and book budget, so that the financial picture in general is not as yet a gray one. Those colleges which have received contracts from the government in the Army and Navy training programs are in some cases more flourishing than before because their regular operating costs can be met in this way. In some cases the Army contracts include a basic allotment (approximately one dollar per man per month) for library service (including books, staff, and depreciation of plant and equipment), but this is, of course, only justifiable where the trainees are using library facilities. Cases such as that in Georgia have been reported, 
however, in which the men in uniform do use the library when the financial provision for this service from the college was not part of the contract. Such an omission cannot be blamed on the Army, which merely approves or questions the contract for expenses as estimated by the college authorities. Some college presidents seem unaware of the library as part of the training facilities offered by the institution, but energetic and wellinformed officials will see to it that future plans for any new undertakings by the institution are considered in the light of the possible usefulness of the library and the demands likely to be made upon it. The provision of books for E.S.M.W.T. courses from federal funds has been mentioned above and applies chiefly to technical schools, though some liberal arts colleges are offering these courses.

\section{Budget Problems Ahead}

The present budgetary situation, however, will not survive a long war nor the straitened period likely to follow it, and college librarians generally are conscious of lean years ahead. As a group we are probably too inclined to accept these with passive resignation. While in theory the library is no longer considered an unimportant part of the college (see public addresses and writings of presidents), in the traditional practice of the budget committee and the accounting department it is still too often grouped with the chapel and the art gallery, which may be in the minds of the budgeteers pleasant but decidedly ancillary adjuncts of education. A sounder philosophy, generally practiced in universities, is to include its budget as part of the cost of instruction and research. The forward-looking librarian will in the spring of 1943 prepare to analyze his place in the college program as a whole, evaluate the library's various services as essential or desirable, and justify the essential in discussion with the administrative authority. The observations of the writer confirm those of the survey made by the librarian of Bard College, recently published in the Library Journal, that the drying up of their essential resources during the coming years is the most serious danger the college librarians have to face and that our best efforts should go into the planning which will insure adequate provision for the book budget and a competent staff. ${ }^{9}$

Most librarians argue that even as a matter of strategy it is not wise to defend your budget from all attacks, since in all probability every department of the college must retrench in time of war or depression. But the librarian should be able to submit what is in his opinion the wisest method of effecting economies whether the proposed decrease needs to be 10 or 20 or 30 per cent of the total. And then he should bring his best eloquence to enforce the argument that below a certain point the quality of library book collection and service cannot go without violating the intellectual integrity of the institution and what it stands for.

\section{The Staff Carries $O n$}

More real than financial difficulties during the past year has been the burden of carrying on the regular and increased activities of the library with the rapid turnover in personnel which the war has occasioned in every type of work. In the professional ranks there has been the inevitable loss of the men of military age and of those who have gone into the serv-

\footnotetext{
${ }^{9}$ Hirsch, Felix E. "The Smaller College Libraries and the War." Library Journal 68:192.95, Mar. I, I 943 .
} 
ice of government, business, or industry on a noticeably higher scale of compensation. This loss has been most keenly felt in the universities and large research libraries. The New York Public Library has lost one seventh of its staff, largely in the higher brackets of subject reference specialists. A few women have left for enlistment in the armed services and for war library work of various sorts. In general, however, professional morale has been strong enough to prevent any largescale exodus into types of war production work which can be performed as well by those with less specialized training, and for the most part the staff has carried on, cheerfully working a little harder and longer to fill the gaps in the line, for it has been the policy of many institutions to avoid general salary cuts by failing to fill the positions of those who resigned unless such positions were considered essential. In some cases infinitesimal increases were made possible by this policy. Very few libraries (though there are some, and again it is the active state colleges) report additions to the staff and a general salary increase in all the lower-paid positions.

In certain libraries located in industrial sections where the War Manpower Commission decrees the forty-eight hour week for all organizations employing more than eight persons and in other libraries where the change will take place in conformity with the regulations controlling governmental and other offices, this increase in scheduled hours of work will produce more problems than additional work accomplished. The necessary 20-25 per cent increase in the compensation of those who work a six-day week, without a corresponding increase in the budget, will make it necessary to reduce the number of em- ployees and will in the medium-sized libraries present serious difficulties in maintaining public service over a fourteenhour day. The Williston Memorial Library of Mount Holyoke College is the only one which has yet reported this situation as existing, though it is expected in many other libraries within the next few months. The librarian of Mount Holyoke has ruled that four of the eight extra hours may be spent in professional reading or in other similar tasks to be distributed throughout the week at the worker's own discretion rather than at scheduled duty.

The chief personnel loss has come in the ranks of clerical, page, and student workers. The replacement of these at greater cost, often with persons of less training or ability, has proved a hardship with the added result of time lost in training a constantly shifting group. The experience of England, where women first took the place of men and were later themselves called up for essential industries, leaving certain types of work to be done solely by shifts of part-time workers, may be repeated here. It might be that faculty wives will form a local source of supply, though as volunteer workers in a war information center one library found them not wholly satisfactory.

No library has reported the substitution of clerical for professional assistants, but Stephens College, indicating a turnover of nearly half the staff, has replaced several trained librarians with highly qualified nonprofessional persons, and in the judgment of the librarian the service has not been impaired by these changes. The report from Stephens does not state whether the new assistants were members of the faculty, but this possibility raises an interesting point as to the wisdom of using 
teachers whose classes may have disappeared in the loss of enrolment. In some cases they might prove valuable additions to the library staff, while in others the personal adjustment would involve difficulties which would be almost insuperable. At Smith College, where the librarian resigned in December, the acting librarian is professor of Greek.

A movement in the opposite direction has been the tendency to use library staff members who are qualified to teach in the emergency replacement of men called suddenly into service. In modern languages, English literature, and political science librarians have stepped into the breach, and when necessary they have been found qualified for a variety of positions from tennis coach to dean of the faculty.

In addition to the war activities of the library as a unit, staff members the country over are reported as participating wholeheartedly as citizens in the many undertakings of the community. It goes without saying that they knit, sew, and roll bandages, serve as nurses' aides, air raid wardens, airplane spotters, blood donors, etc. Except in areas where a larger public library nearby directed the Victory Book Campaign, the college libraries have been responsible for this effort and in all cases they have furthered it by campus action. As in many other instances, a traveler is impressed by the quality of work accomplished in the small institutions by a library staff composed of energetic people. The large library will put out a barrel and a poster, accepting passively what the students provide, and because of their number a fairly respectable total results, even though many of the books are old texts and must be discarded as useless. In a small college in Monmouth, Ill., for example, the librarian by a cleverly written appeal, based on personal reference by name to the men who have gone to war from the campus, induces the students to part with, even to buy "a book for Corky Kilpatrick in Africa, Herb Merillat in Guadalcanal, for former editor Larry Beth, and Bobby Dunlap who left only a few weeks ago...." The appeal continues, "Dedicate a book to one of these boys you know and give it to the campaign, knowing whoever reads it will experience the same enjoyment that you intended for your friend." This brought results, as one would expect, and though the number of volumes collected on college campuses does not always seem high if compared with the larger populations of the community outside, many librarians have commented on the average good quality of the books received.

\section{Delays and Difficulties}

Few libraries have as yet curtailed their regular services except in the matter of closing some departmental reading rooms and consolidating others. Often this reorganization results in more efficient service as well as economy of administration. One library notes a considerable increase in the use of the telephone for reference service. In some cases rare book rooms and special collections are no longer staffed and are opened only on request. In other colleges reading rooms are being closed on Friday nights and Saturday afternoons, when the student use is too slight to justify opening. But in general the libraries are open for business as usual for a fourteen-hour day or longer, six days a week.

The trials which are accepted as part of wartime living are chiefly delays, the 
slowing up of publishing and purchasing machinery, delayed deliveries, delays in binding when demands for haste are more insistent than ever. There are few explicit reports of increased costs of operation though one institution in Vermont estimates a Io per cent increase in binding costs and 8 per cent in cards. A number of libraries bought equipment and supplies in greater quantity than usual, anticipating that the present shortage will grow more acute.

The cessation of foreign book selling and of all periodicals from Europe has reduced the purchasing problems of academic libraries to some extent and thrown the budget out of balance, but books continue to come with surprising regularity, if some delay, from England. South American purchases are readily arranged and more rapidly received than formerly. A number of books in French and German are procurable in South America, and libraries have been quick to subscribe for the several French periodicals published there and in eastern Canada as well as in New York, which contain the current writing of the exiled French authors who were formerly the leading contributors to the scholarly and literary journals ordered from Paris. The whole question of foreign journals is still in process of solution. The enterprise of University Microfilms, Inc., should be noted. $\mathrm{Li}$ brarians may notify the Custodian of Alien Property concerning additional titles which they desire to have filmed.

While no one familiar with the inner workings of libraries would ever accuse them of prodigal spending, it is also possible that occasional lean, or perhaps leaner than usual, years are a wholesome experience for us in forcing a close scrutiny of routine practices or traditional services.
The required continuity in the nature of our work tends to perpetuate whatever is once started, sometimes after the need has passed away.

Knox College reports plans for continuous study and reorganization of its library. Bradley has reduced its circulation routine as the result of a time and motion study. Catalog processes are under careful consideration in many quarters and it is probably in this direction that useful simplification and economy will be effected. It is said that the last war eliminated the accession book from many a library, and this one may go down in history as the event which brought action in the long argument over the varieties and degrees of cataloging which are desirable or necessary.

College and university library reports in the past year everywhere indicate a realization of responsibility for the care and preservation of treasured volumes, original sources, and valuable editions which may well prove the source material for future duplication of the books destroyed in war. Some Eastern libraries packed and shipped irreplaceable volumes to locations further inland and probably safer in the event of enemy attack. Many others, fearing the damage which might occur in long storage and preferring to have their rare materials accessible in case of genuine need for consultation, segregated them in portions of the building which seemed least vulnerable.

\section{Policies of Acquisition}

The squirrel complex to save everything within reach, which is an occupational disease with the average librarian and for the most part a blessing to historical research, should nevertheless receive curative treatment to the extent of divid- 
ing its responsibilities and distributing its benefits. Too many libraries today are collecting everything they can get about the war. Yale has asked every Yale man the world over to send in every scrap of original war material he can find, and the haul is already imposing. The Hoover Library of War, Peace, and Revolution, at Stanford University, has an organization already equipped and in operation for the systematic collection of documentary and other material. Here are two scholarly institutions situated well apart, both suitable depositories for all such printed records as the future may need. Why not give them everything the rest of us get except local material for which each of us accepts local responsibility? Or if two centers are not enough, why not establish regional collections and let others collect in smaller, well-defined fields?

Cooperative buying too has long been the topic of papers at library meetings, but few of us get further than expecting the other person to cooperate. In rare instances, particularly when funds from foundations are concerned, complementary buying programs have been worked out. The specific division of the Latin American field among the libraries of Duke, Tulane, and the University of North Carolina, on a joint grant from the Rockefeller Foundation, is an excellent example of what might be done more consistently by neighboring institutions in various regions. ${ }^{10}$ The University of Michigan, because of certain faculty interests in the field, is also embarked on a program of buying heavily in Central and South America, although the director of its libraries points out that Canada would be

${ }^{10}$ Lowell, M. H. College and University Library
Consolidations. Oregon State System of Higher Consolidations. Oregon State Syster
Education, Eugene, Ore., I942, p. 40.

JUNE, 1943 a more logical and less competitive field for its endeavors.

All academic libraries, to be sure, need a certain amount of material on Latin America, Russia, and China, and all are now intent on strengthening their collections in what are for some relatively new fields of interest. But we should definitely limit those interests to the books necessary for teaching and reference, dividing the realm of specialized research into regional responsibilities and agreeing to serve each other through interlibrary loan and microfilm for the research scholarship of the future. This division in the library of Oriental studies is particularly desirable on the Pacific Coast.

Libraries are already making plans for future purchase abroad of books which have appeared during the war years or of collections which may come upon the market after the war in Europe and Asia. Many are setting aside substantial funds for this purpose. Yale has plans for sending an agent to the Near and Middle East. The University of California is talking of collecting on the spot in China at the earliest possible opportunity. The director of the National Library at Peiping has outlined inspiring plans for the rehabilitation of Chinese libraries with American aid and will undoubtedly cooperate in the undertaking of strengthening the Chinese collections in the libraries of this country. Many libraries are already collecting from their faculties personal copies of scholarly journals for later shipment to Chinese and European libraries, under the direction of the A.L.A. Committee on Aid to Libraries in War Areas. The air is full of library plans for international cooperation, a heartening sign in the present world and a reminder that despite all wars better days do come 
in which men of goodwill may go about their business of building again singly and together.

\section{Present Conclusions}

Yale University Library reminds us that the college has survived nine wars. In this rapid flight over the country which has afforded glimpses of only a few colleges and none so venerable as Yale, the reporter has been impressed nevertheless with the essential stability of collegiate institutions. Their students come and go, the flags and the uniforms will pass, the curriculum will change, but the purposes of truth and learning endure. To fulfill these purposes libraries exist and will continue to grow. The test of their successful functioning is the contribution to knowledge made by the faculty and the degree of understanding which the students derive from books.

In April 1943 the importance of every American institution or endeavor must be measured in terms of its relation to the total war effort. Does it help or hinder? In terms of research the academic libraries have given a clear answer. The government has called upon them and not found them wanting in the required aid to science and techniques.

Wisdom and understanding, however, are equally necessary in the present crisis, and in the realm of student education to this end we cannot claim conspicuous success as yet. Here then is the task ahead for every college, large or small, and for the colleges within the large universities where it has been chiefly neglectedto provide the necessary books, pamphlets, and periodicals in sufficient quantity and to stimulate their use by every means in our power. By all means let us extend our functions beyond the walls with war information services if and when we can, but remembering that other agencies may also serve this wider community while the responsibility for student reading is ours alone.

\section{Future Plans}

One of the few excitements in a somewhat staid calling is the satisfaction of what the librarian of Wellesley describes as "prophetic buying," the justification in present use of one's past judgment in the development of certain areas in the collection or in the choice of specific titles which prove to be finds. The librarian who is to be ready must forecast needs, and even now in time of war we can prepare for carrying on the studies necessary if peace is to endure. The fact that the urgency of military training is fast draining the majority of students from classes in the humane and social subjects in no way lessens the future need for strong collections in these fields. There will be a resurgence of interest in the things of mind and spirit such as follows every conflict; there will be enlarged programs of rehabilitation and reconstruction, as well as those for occupational therapy and vocational adult education, and in all these endeavors the library will do its part.

Academic librarians are by nature and training neither crystal gazers nor wishful thinkers. For the immediate future they have few rosy-tipped prophecies but a steadfast determination to carry on the allotted task, to bear a full share of the common war burden, and to preserve the permanent values for which their work exists. If they can do so through this period of stress, certain strengths should develop in their libraries which will leave them in a better position after the war, 
both internally and in relation to other departments. The wholehearted participation of the library in all the activities of the institution it serves during a period of war will bring about better integration in the life of the campus and the community outside, which may for the first time have learned to know the college library. Work with administration, faculty, and students in a common cause will bring to each better understanding of the other's problems. If the library's work is sound and its service effective, there is no reason to foresee a permanent crippling of that work, provided that the librarian has enough faith in its value to defend it against indifference or lack of understanding on the part of authorities. Publicity alone will not do this, but good work first plus a valiant coming-out-from-under-the-bushel in which college librarians have too long hidden their light may accomplish wonders.

A few hours spent in reading the annual reports of academic libraries impresses one with their similarity in pattern and general lack of effective power to produce results. Follow this by a glance at the corresponding report of the president to the trustees and the reason for inaction is obvious. The librarian's report almost invariably deals with acquisitions, gifts, resignations, etc., a faithful recounting of what has happened to the library, with an appendix of circulation statistics meaning little to the uninitiated. The president, skipping the statistics and any troubling references to the leaky roof or the need for more stack space, reports to the trustees the more imposing of the gifts and the activities of the Friends of the Library. The trustees purr approvingly at the annual meeting following the commencement luncheon and forget the library until next year.

Compare this with the graphic reports prepared by some of the public libraries, such as that of Detroit, ${ }^{11}$ which is an excellent example. These are designed to render to the board and thus eventually to the taxpayer an account of the library's stewardship of public funds. The emphasis is all on what the library has accomplished and what it could do or plans to do.

An ideal library report should recount briefly the year's activities with reference to the plans outlined in that of the previous year. With proper record of what has been spent and acquired it should carry also some reference to the intangible but no less real accomplishment of the library in its direct service to faculty and student bodies: in aiding the faculty in research and teaching, in helping the students to attain intellectual maturity. It should leave an impression of forward vision and include, not timidly modest hopes, but demands as daring as the visions deserve-though not more so. In other words, the report should perform the functions of a preliminary bombardment for the detailed attack on the budget to follow.

Only with foresight, vision, and energy can college libraries hope to carry on effectively both the war service which calls them today and the larger task of tomorrow which is theirs also, a share in the education which will shape the world of the future.

1 The Library in Wartime. Seventy-seventh An. nual Report of the Detroit Library Commission, I 94 I-42. I $8 \mathrm{p}$. 